This item was submitted to Loughborough's Research Repository by the author.

Items in Figshare are protected by copyright, with all rights reserved, unless otherwise indicated.

\title{
Panelism in Action: Labour's 1999 European Parliamentary candidate selections
}

PLEASE CITE THE PUBLISHED VERSION

PUBLISHER

(c) Blackwell

LICENCE

CC BY-NC-ND 4.0

REPOSITORY RECORD

Wring, Dominic, David Baker, and David Seawright. 2019. "Panelism in Action: Labour's 1999 European Parliamentary Candidate Selections". figshare. https://hdl.handle.net/2134/1086. 
This item was submitted to Loughborough's Institutional Repository by the author and is made available under the following Creative Commons Licence conditions.

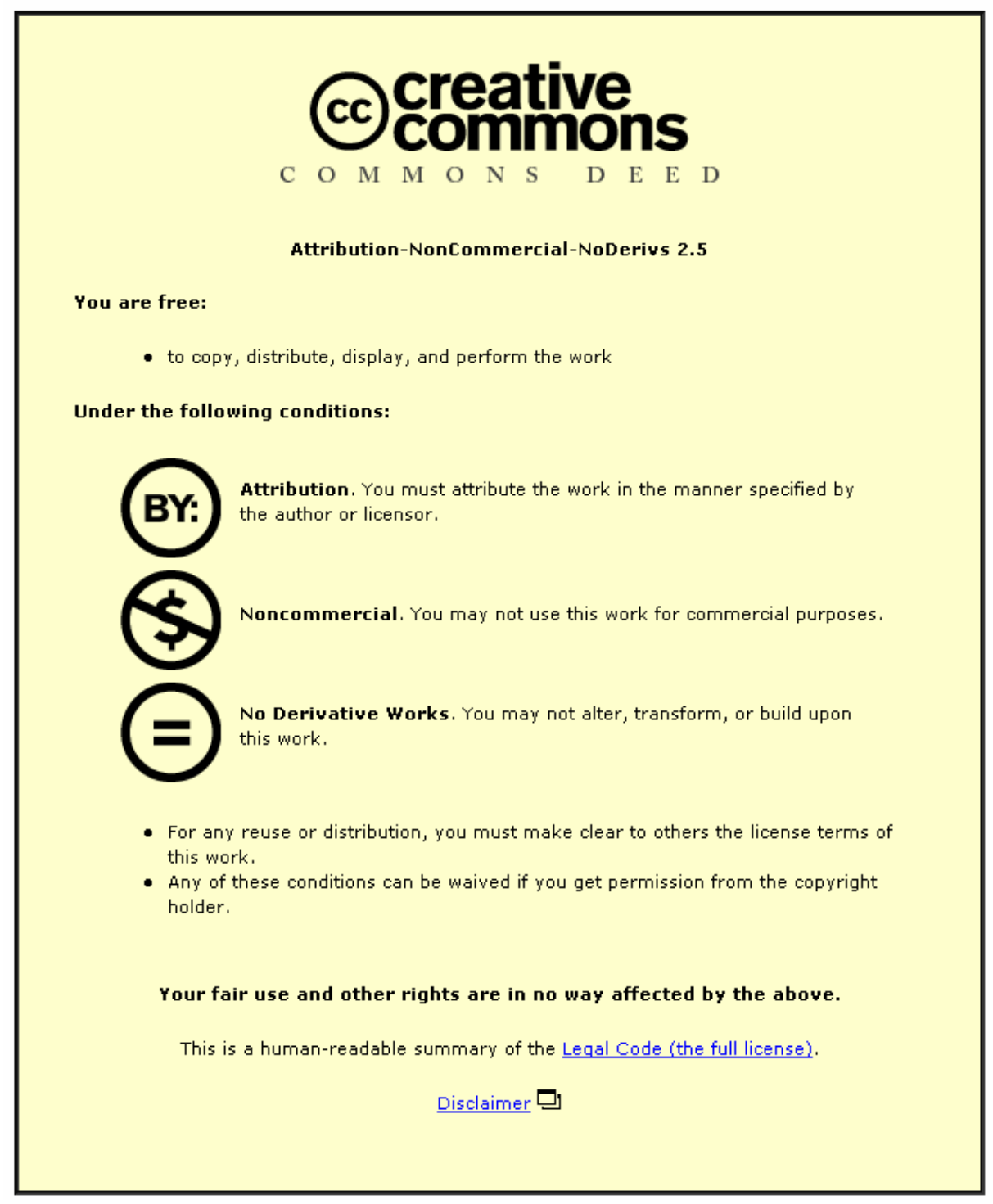

For the full text of this licence, please go to: http://creativecommons.org/licenses/by-nc-nd/2.5/ 


\section{Loughborough University}

\section{Panelism in Action: Labour's 1999 European Parliamentary Candidate Selections.}

Dominic Wring (Loughborough Univ)

David Baker (Nottingham Trent Univ)

David Seawright (Leeds Univ)

The Members of Parliament Project

Paper presented at the PSA EPOP Conference

Northampton University College

September 1999 


\section{Panelism in Action: Labour's 1999 European Parliamentary Candidate Selections.}

\section{Introduction.}

The 1999 European Assembly elections were fought under newly devised rules. The adoption of a more proportional electoral procedure in place of the traditional single member majoritarian system was designed to bring the UK into line with the other EU member states. This departure from 'first past the post' necessitated a change in the way prospective Members of the European Parliament were selected. In the event this proved controversial. Of further contention was the decision to adopt a closed list system whereby electors were not able to vote for a preferred candidate. Prospective MEPs were thus numerically ranked in multiple member constituencies.

The selection of European parliamentary candidates attracted considerable media interest. Various newspapers covered, with relish, the purging of Europhiles from the already minimal compliment of Conservative MEPs. Aside from Tom Spencer, who resigned for personal reasons following revelations about his personal life, others such as Brendan Donnelly and John Stevens declined to serve as candidates following their effective demotion by the party's selection procedure. Donnelly and Stevens took their grievance further and formed a new organisation, the Pro Euro Conservatives, in order to (unsuccessfully) contest the forthcoming elections. Another Europhile, London MEP James Moorhouse, left the party for the Liberal Democrats in protest at William Hague's policy pronouncements. By contrast the new crop of prospective MEPs appeared to reflect the strong strain of Euroscepticism within the Conservative grassroots. The Hague leadership welcomed membership involvement in this matter. By contrast the Labour hierarchy proved more circumspect about its candidate selection procedure. This paper seeks to assess whether there is substance to the charge that the new system has in effect enabled officials from the Millbank headquarters to dictate who would and would not become MEPs. 


\section{The Origins of 'Panelism'.}

The rise of the Labour left in the 1970s and early 1980s culminated in a number of important organisational changes designed to give more influence to activists within the party grassroots. The commitment to internal reform, promoted by groups like the Campaign for Labour Party Democracy, centred on a number of issues to do with policy formation and candidate selection. On assuming the leadership in 1983 Neil Kinnock, an erstwhile standard bearer of the left, began to break with his former comrades. One critical way in which he did so was to press for a system of One Member One Vote whereby everybody belonging to the party would have a say in candidate selection. This direct form of democracy would have challenged Labour's newly enhanced representative structures and, in so doing, the increasing influence of left activists within the organisation.

Kinnock did not succeed at his first attempt to introduce pure OMOV in 1984. Following the 1987 election defeat significant reforms did take place whereby members obtained the right to play some role in leadership and candidate selection ballots. Most importantly the leadership, through an increasingly compliant National Executive Committee, began to exert increased control over the symbolically important business of by-election candidate selection. ${ }^{1}$ In a series of controversial cases the centre demonstrated its determination to impose its will on regional and local parties. It did so by the use of a special NEC taskforce, or panel, charged with coordinating selection procedures. In many cases the process was straightforward but in several it was not. The workings of the NEC by-election taskforce are important because they offer an insight into the origins of 'panelism', a system whereby de facto control of candidate selection passes from the ordinary voluntary membership to the party professionals.

By-elections offer a peculiar challenge to parties and single results can and do have serious political consequences. The shock Liberal victory at Orpington in 1962 undermined confidence in the then Conservative premier Harold Macmillan and helped precipitate his resignation.

\footnotetext{
${ }^{1}$ Shaw, E. (1994) The Labour Party since 1979. London: Routledge, pp.114-17.
} 
Similarly the party's poor third place in the Bradford North contest of 1990 reinforced Margaret Thatcher's precarious position and she was forced out soon after. The infamous Bermondsey campaign of 1983, in which Labour lost a safe seat to the Liberals, damaged the then Labour leader Michael Foot's standing. By-elections can, however, also enhance politicians' repuations. Labour's victory in Darlington over the newly founded SDP in the year running up to the 1983 general election did much to secure Foot's position as leader. More often though it is the defeats that are remembered. Months before the 1987 general election, Foot's successor Kinnock faced a crucial test in the Greenwich by-election. Labour candidate Deirdre Wood was subjected to a ferocious media campaign which ultimately contributed to her SDP rival's victory. The loss of this previously safe seat demoralised party morale at a critical moment. ${ }^{2}$

The events of Greenwich and subsequent internal inquest encouraged the NEC to take a greater role in the candidate selection process. The move for this kind of reform was augmented by another embarassing by-election defeat, this time after the general election. Glasgow Govan had been the safe Labour seat of former minister Bruce Millan. Millan's decision to become a European Commissioner forced a by-election. Once again media scrutiny undermined Labour candidate Bob Gillespie and helped his combative SNP rival Jim Sillars to take the seat on a huge swing. Some in the leadership, weary of Gillespie's left politics, once again questioned whether party members were the best equipped people to choose candidates for these potentially high profile campaigns. Ironically comparatively less was made about the local unpopularity of the decison, taken by Millan in consultation with Kinnock, which had caused the by-election.

Following Greenwich and Govan, every subsequent Labour by-election candidate was subject to scrutiny from the central party. This was done through the institution of a special NEC vetting panel. When the Pontypridd seat fell vacant in 1989, there was speculation whether the local party's chosen standbearer, Kim Howells, would be endorsed and allowed to stand. Howells, a personal friend of Kinnock, did in fact go on to fight and win the seat before becoming a member of the Blair government. Other prospective MPs were not so fortunate.

\footnotetext{
${ }^{2}$ Heffernan, R. and Marqusee, M.(1992) Defeat from the Jaws of Victory. London: Verso, pp.72-74.
} 
When the Yorkshire coalfield seat of Hemsworth came vacant in 1991 several groups within the Constituency Labour Party nominated Ken Capstick, a prominent member of the National Union of Mineworkers, as their choice for candidate. In spite of his local popularity Capstick was blocked by a central apparatus weary left-wing policy positions. When former Leeds MEP Derek Enright was chosen the decision caused an outcry within the local party. The Labour leadership nevertheless felt vindicated when they retook the seat albeit on a lower turnout and diminished majority.

The end of the Kinnock leadership did not precipitate a change in the centre's hold over byelection campaigns. Following the introduction of pure One Member One Vote in 1993 the NEC panel continued to vet all nominees for vacant seats. In doing so it continued to play a critical role in the process. Prior to the Rotherham by-election of 1994 the panel excluded popular local activist Pete Thirlwell despite his several nominations from within the constituency. Thirlwell, it was claimed, lacked sufficient media skills. This was not a accusation levelled at successful candidate Denis MacShane, a past President of the National Union of Journalists. Leadership favoured MacShane had been a contender for the seat's nomination prior the general election and was thus well known locally. In a shortlist with several less fancied rivals he won a ballot of the membership and then the by-election itself.

The ability of the NEC panel to exclude locally popular and amply supported nominees has proved crucial in other by-election selections. In 1994 Jon Cryer's attempt to succeed his late father and fellow left-winger Bob as Bradford South's MP was curtailed by the national party. The panel shortlisted four nominees but Cryer was not included despite his several nominations. Only one of these, council leader Gerry Sutcliffe, was well known locally. Sutcliffe won the subsequent ballot with ease. Similarly when the spotlight once again fell on Hemsworth following Derek Enright's sudden death, the central party refused to allow another locally popular and NUM backed candidate, Steve Kemp, onto the shortlist for the by-election. ${ }^{3}$ The eventual victor in the selection, Leeds City Council leader Jon Trickett, was a local politician

\footnotetext{
${ }^{3}$ The Guardian 5th December 1995.
} 
well known to national officials. The decision underlined how 'panelism' would continue to play a role under the new leadership of Tony Blair. 


\section{From 'New Model' to 'New' Labour.}

Talk of 'control freakery' has increased during the leadership of Tony Blair. Blair himself played a significant role in the symbolically important first by-election that followed Labour's landslide victory and return to office in 1997. Uxbridge had returned the sitting MP Michael Shersby by a small majority. Following Shersby's sudden death hours after polling, Labour had the chance to take another seat at the very height of its popularity. Supporters of the NEC panel had claimed it worked because it produced popular candidates capable of winning. The experience of Uxbridge challenged this view when, following considerable local opposition, Labour's general election candidate David Williams was excluded from a two person shortlist. Barely weeks after he had nearly been elected, Williams was now deemed not sufficiently credible to contest the seat by his own party leadership. Breaking with tradition, Blair visited the constituency to personally endorse and boost the campaign of new (or perhaps 'New') Labour candidate Andrew Slaughter. The appropriately named Slaughter, a councillor from outside of the borough, was defeated with the locally based Conservative actually increasing the party's majority.

The practice of 'panelism' is not then a purely New Labour phenomenon but a legacy of the Kinnock and Smith leaderships. Crucially though this mechanism for exercising control is being expanded and used to police various selection procedures. In the run up to the 1999 elections for the new Scottish Parliament and Welsh Assembly the party convened special panels to oversee and monitor the process by which candidate would be chosen. The system produced several high profile casualties, most notably in Scotland. One Westminster MP, Denis Canavan, was expelled from the party when he opted to fight his own seat having failed to win the nomination. His comfortable election to the Scottish parliament appeared to vindicate his stance against 'control freakery' and succeeded in highlighting the wider popular support that existed for his position.

The constitutional reform process has also produced a new tier of regional government for the capital city. In 2000 Londoners are due to vote for a new assembly and will also have the 
chance to choose the country's first directly elected mayor. Labour MP and leading left-winger Ken Livingstone has already expressed an interest in standing. Livingstone was previously leader of the last capital wide strategic authority, the Greater London Council. A key centre of opposition to the then Thatcher government, the GLC was abolished in the mid-1980s. Despite his campaigning abilities and media skill, Livingstone's opposition to government economic policies has raised speculation that Blair and the central party will prevent him becoming Labour's mayoral candidate. This will almost certainly be done through an NEC panel empowered to exclude nominees from a decisive ballot of the sizeable city wide membership. ${ }^{4}$

Understandably the setting up of new tiers of Scottish, Welsh and London government has attracted a degree of media interest and speculation. But perhaps the most revealing series of elections in terms of Labour party candidate selections were those that took place before the 1999 European Assembly poll. Here the practice of panelism was not being extended to a new set of candidatures in one particular geographical region of the country but involved the whole of the party nationwide. Furthermore the selections involved an existing group of parliamentarians, many of which had expressed a desire to continue for a further term. Elected at various times in the previous twenty years, the members of the European Parliamentary Labour Party (EPLP) included people of various persuasions and factional backgrounds. Given the introduction of a new electoral system almost certainly meant a decrease in the overall number of Labour MEPs, the process for choosing candidates was destined to a particularly sensitive task.

\section{The Party into Europe.}

As successive name changes suggest, EEC/EC/EU member states envisaged a more politically integrated partnership. The Thatcher and Major governments were critical of this position and those behind it. Foremost amongst the politicians in the drive for greater integration was

\footnotetext{
${ }^{4}$. Similar acrimony has surrounded the selection of some Welsh assembly candidates and has continually dogged the run-off between Welsh Secretary Alun Michael and his rival Rhodri Morgan for the nomination to be First minister in the new Assembly or 'prime minister of Wales'. For details of this and other controversies see, for instance, The Guardian 10th November 1998.
} 
President of the European Commission Jacques Delors. In manner and background social democrat Delors appealed to the leaders of the Labour party and Trades Union Congress in Britain. Both put considerable resources and time into cultivating links with like-minded organisations within the EC/EU. Indeed when Labour almost quadrupled its number of MEPs in the four successive Assembly elections held between 1979 and 1994. This greatly increased its political influence with the party becoming the largest single group within the parliament. Unsurprisingly the EPLP became a useful resource in the party's overall strategy of opposition during the 1980s and early 1990s. The stature of the group was underlined when, following the successful 1994 elections, London MEP Pauline Green became leader of the Party of European Socialists.

The new electoral system, the so-called 'closed list' formula, introduced for the 1999 European Assembly campaign attracted considerable opposition from across the political spectrum. Supporters and opponents of electoral reform united in condemning the rule revision. The legislation was attacked in parliament and at one stage it looked possible it might not proceed through the House of Lords were it was mercilessly dissected by Conservative spokespeople. Many believed the principle of voting for a regional party list conflicted with the British tradition of electors being able support a single named candidate. Others expressed disquiet about the potential divisiveness of the proposed system. The use of rankings, it was argued, would further a party leadership's influence over the process of candidate selection. ${ }^{5}$

There were four principle stages in the selection of Labour candidates for the European Assembly. In the initial phase all sitting MEPs were consulted as to whether they wished their names to go forward. Each of the soon to be dissolved European constituency parties were invited to endorse their sitting MEP and nominate and then vote for one man and one woman to go forward to the final selection. The next stage consisted of an OMOV ballot to determine

\footnotetext{
5 The new system meant Labour needed to select candidate lists for 11 of the 12 UK regions (the exception being Northern Ireland). These are (with the number of seats in brackets): Scotland (8); North (4); North West (10); Yorkshire and Humberside (7); Wales (5); West Midlands (8); East Midlands (6); Eastern (8); South West (7) Greater London (10); South East (11).
} 
who amongst those shortlisted should go forward. Given more names went forward than list places existed, it was perhaps inevitable that there would be some disappointment.

The last two phases of the process proved to be the most contentious. For the third stage candidates had to complete a questionnaire detailing their experiences and motivations. Assistant General Secretary David Gardner and another regional official graded the reportedly 'nameless' papers. The records and performances of sitting MEPs were also evaluated. The final element in the convoluted selection procedure involved the convening of NEC endorsed panels of national and regional officials and representatives. Candidates were interviewed, invited to make a presentation and also cross-examined in a mock press conference to ascertain their political outlook and media aptitude.

The selection procedure produced a set of marks for each candidate. These were collated and a 'consensus' meeting of officials and representatives convened to determine the rankings. The committee had a wide and influential remit given it was reportedly able to protect existing 'talent', foster the interests of women and minority nominees, and also 'shoehorn' candidates onto other regional lists. ${ }^{6}$ If those involved were in need of any further reminder, an independent academic report for the European public affairs consultancy Adamson Associates reinforced the importance of candidate order in the new list system.

The report estimated each party's projected number of MEPs based on several different projections of their vote share. Weary that the favourable opinion poll ratings might not be reflected at the polls, Labour officials took a cautious view of the Adamson projections and suggested the party's European representation might be cut to $34 .^{7}$ Such a gloomy prognosis may have influenced the selection committee. At the very least it would have underlined the fact that the particular order of ranking would be crucial in determining who got elected and who did not. A place at the top or bottom of the list in this campaign pre-determined a Labour

\footnotetext{
6 'Labour HQ denies polls "stitch-up" ', The Guardian 19th November.

7 The Independent, 18th November 1998.
} 
candidate's fate. A move up or down of just one place in the various intermediate positions could, however, make all the difference. 


\section{The Outcome in 1999.}

Approximately two thirds of the 62 Labour MEPs returned in 1994 contested the 1999 Assembly elections. 22 of these 41 nominees were returned as MEPs. 43 other candidates filled the remaining places on the final party lists; only seven of them were successful. Labour under Blair had experienced its first major electoral setback. Having almost doubled the size of their parliamentary group, the Conservatives celebrated victory and claimed vindication for their determined anti-Single Currency campaign stance. The Liberal Democrats also expressed satisfaction at having greatly increased their representation. The Scottish Nationalists consolidated their position and were now joined in the Assembly by their Welsh allies Plaid Cymru. The Greens and UK Independence parties also took their first ever seats in the Assembly.

Some commentators, particularly those close to the leadership, blamed Labour's poor performance on the low voter turnout. Others, such as former MEP Shaun Spiers, argued the party had not effectively campaigned nor developed a coherent message to counter the populist Eurosceptic rhetoric of the Conservatives. ${ }^{8}$ There was also a widespread belief that neither the party campaigns nor voters best responded to the new, more complex and proportional electoral system. Some in the grassroots' structure complained that the workings of the list system disempowered and thusn demotivated the local memberships. Consequently they failed to provide an adequate pool from which voluntary campaign labour could be drawn. ${ }^{9}$ Ironically the results provided the leadership with some compensation. Had the election been fought under the old system, the same vote share would have probably further reduced the already limited number of Labour MEPs.

\footnotetext{
8 Tribune 2nd July 1999.

${ }^{9}$ For instance the parting shot of former candidate Joyce Edmond Smith who withdrew from the selection process, complaining panels in 1999 were no decent replacement for the OMOV system that had been adopted for the 1994 round.
} 


\section{Analysing the Selection Procedure.}

In assessing the outcome of the parliamentary selection process several pertinent questions arise. Did race or gender play a factor in the ranking of candidates? The party reportedly wanted to increase its number of ethnic minority and women MEPs. Did this commitment register in the outcome of the selection and then the election proper? Did age, background and/or parliamentary experience make any perceptible difference? Were younger people encouraged through the process? Did people with manual working-class backgrounds still prosper? And were the more experienced parliamentarians being effectively retired?

Arguably the most interesting question relates to whether MEPs were ranked according to their ideological viewpoint. It is notoriously difficult to determine this quality, even in a historically fractious party like Labour. The emergence of 'New' Labour presents a further problem. However on the defining issue of Clause Four reform the EPLP publicly split over a crucial intervention midway through the debate. The initiative took the form of an advert sponsored by Alex Falconer and countersigned by 31 of his fellow MEPs. The piece, a call for the reaffirmation of Clause Four as it stood, first appeared in an edition of the weekly left newspaper Tribune and attracted little comment at the time.

In early January Falconer re-advertised the text in The Guardian to coincide with a visit by Tony Blair to Brussels. On the day it appeared the same newspaper made the item front page news. ${ }^{10}$ The move was interpreted as an act of defiance. The leadership reacted by briefing sympathetic journalists about how, in a meeting with the whole EPLP, Blair denounced the 'infantile incompetence' of those signatories to the letter. Blair reportedly rejected a call for the renationalisation of key utilities from 'friend' and MEP David Hallam by telling him to 'grow up'. ${ }^{11}$ The leader's petulant tone contrasted with his stated commitment to an open debate over the party's constitutional settlement. Indeed Blair was quoted as saying he would now use the

\footnotetext{
10 The Guardian 10th January 1995.

11 'Angry Blair slaps down rebel MEPs', The Guardian 12th January 1995.
} 
incident to censor colleagues' public utterances: 'Every member of the frontbench must check their policy statements and adhere to our policy making process'. ${ }^{12}$

The flurry of publicity surrounding the advert was enough to make three signatories almost immediately recant their previous support for the Falconer statement. They were eventual joined by four other colleagues. ${ }^{13}$ The seven, together with 29 of the other 30 MEPs (including all of the senior EPLP officers), endorsed a letter of reply co-ordinated by group leader Wayne David to The Guardian. The David text was sympathetic to the leadership: '(W)e welcome Tony Blair's initiative in inviting the Labour Party to debate how best to serve the interests of the British people into the next century'. ${ }^{14}$ The initiative attracted considerable and sympathetic coverage in the same paper's news reportage. MEPs had, by their actions, given an important indication of their support for the 'old' Clause Four (or something similar) or a 'new', Blair sponsored version (as yet to be determined, but there were indications that the wording would underline the party's acceptance of market economics).

\section{Results of the Selections.}

If those MEPs who signed the Falconer statement are taken to be the supporters of 'old' Labour Clause Four, those who endorsed the rival David letter can be termed the 'new' group. In this way it will be possible to assess how both tendencies fared in terms of the rank position each 'extant' MEP obtained on their respective regional list. This variable was further dichotomised into positions ' 3 and above' and ' 4 and below'. Being ranked at 3 on a Labour party list did not guarantee a candidate would be elected because the regions differed in the numbers of Members they returned. Furthermore the different multi-member constituencies varied in their partisan allegiance. Consequently a ranking in one region did not automatically transfer to another in terms of marginality. However positions 3 and 4 appear suitable cut off points because they do

\footnotetext{
12 The Guardian 12th January 1995.

13 These were Alan Donnelly (soon to be the new Group leader), David Bowe and Hugh McMahon, The Guardian, $11^{\text {th }}$ January 1995.

14 The Guardian 12th January 1995.
} 
suggest something about the likely electoral chances of a given candidate: those ranked in the higher bracket were much more likely (and did, in a majority of regions) become MEPs.

All those elected in 1994 were included in the study as were the two MEPs returned in byelections during the parliamentary session. The five candidates elected in 1999 for the first time were added to make a total sample of 69.20 of these did not, for various reasons, contest the elections as Labour candidates because they had retired or fallen out with the party. In Tables 1 to 4 these ex-MEPs are listed as 'not standing'.

Table 1 suggests Labour is making some progress in its bid to increase its compliment of women MEPs. Men still, however, outnumber the women in our dataset by a ratio of approximately 2:1. Crucially though $80 \%$ of the female candidates of the those in the sample who stood were ranked ' 3 or above' in their list as opposed to only $59 \%$ of the male contingent. The small number of 3 Asian or Black politicians in the sample make it difficult to make any conclusive judgement about ethnic minority representation except to say, with two MEPs, it had in effect doubled. ${ }^{15}$

\section{TABLE 1 ABOUT HERE}

Tables 2 and 3 suggest their has been a 'cull' of older Labour MEPs. 16 of those standing down in 1999 were aged 60 or above. 13 of those retiring were also amongst the most experienced MEPs given they were first elected in either 1979 or 1984 . Conversely 21 (or 43\%) of the 49 candidates who contested the campaign in one of the coveted ' 3 and above' slots were aged 3049. ${ }^{16}$ Similarly 26 (or 53\%) were more recent entrants to the parliament, having been elected in 1989 or 1994.

\footnotetext{
${ }^{15}$ Asian candidates Neena Gill (West Midlands) and Claude Moraes (London) were elected though the only Black MEP, Mark Hendrick (North West), was not due to a low ranking.

${ }^{16}$ Youth was not necessarily a guarantor of reselection in a winnable ranking. One of the youngest MEPs, Shaun Spiers, was placed low down on the London list despite his articulate and informed contributions to the Single Currency debate. An opponent of the scheme, Spiers had also been a signatory to the Falconer advert.
} 


\section{TABLES 2 AND 3 ABOUT HERE}

In Table 4 it is possible to see how, amongst those not standing in 1999, there is a disproportionately high number of 'old' Clause Four supporters. 'The decline of this 'wing' of the party can also be detected in these candidates’ aggregate rankings in the regional lists. Only $36 \%$ of those 'old' Labour MEPs standing obtained a placing of ' 3 or above'. By contrast some $67 \%$ of those identified as 'new' in outlook received the same ranking in their respective regional lists. ii The figures tend to suggest that 'panelism' may have worked to provide the Blair leadership with a more compliant and modernising group of MEPs. ${ }^{\text {iii }}$ That said none of the cross-tabulations were statistically significant. At .080 the ideological 'new' versus 'old' Labour variable came closest. ${ }^{17}$

\section{TABLE 4 ABOUT HERE}

Table 5 shows the results of running a logistic regression analysis. This was done to allow an estimation of the probability that being in the 'new' Labour category would greatly enhance a candidate's chance of being selected in the ' 3 or above' section of a list. Moreover logistic regression technique was chosen because the dependent variable, 'position on list', was dichotomous. $^{18}$ The Table suggests that there is a greater probability of 'ideological position' rather than age, race, gender or cohort (year MEP entered parliament) being the factor that most determines whether a candidate is placed in the category ' 3 or above'. The NEWLAB variable is the only significant one at the .05 level (.0236).

\section{TABLE 5 ABOUT HERE}

\footnotetext{
17 This is unfortunately a perennial problem with the study of parliamentary parties where the $\mathrm{N}$ is naturally a small one.

${ }^{18}$ Norusis, J.M.(1994) SPSS Advanced Statistics. Chicago.
} 


\section{Conclusion: Liquidating the Left?}

The elections for the new, devolved Scottish parliament and Welsh Assembly have understandably attracted considerable media coverage. The procedures Labour used to select its candidates for both bodies were selected attracted particular controversy and speculation. Similarly the European elections, held a month later, offer an opportunity for a reappraisal and assessment of the extent to which the party leadership has been able to influence the process of candidate selection. Significantly this process covered the whole of the party nationally and as such may provide something of an insight into how Millbank may try and influence the forthcoming round of selections for prospective Westminister MPs. Central to the leadership’s acquisition of power in this important sphere of party activity has been the practice of 'panelism' in which agents of the NEC have been willing and able to act in a partial manner against those parliamentary hopefuls deemed unsuitable on the grounds of their politics.

Honed in the long period of opposition first under Kinnock and then Smith, panelism developed as means for managing local parties' choice of by-election candidate. This same procedure drove the selections for the European Assembly. OMOV had been used for the first time in the 1994 round in place of electoral colleges and General Management Committee votes. The use of committees in 1999, this time convened by the party nationally, made the switch from OMOV all the more startling. The results of the process have, similarly, been stark. For the first time no members of the left-wing Campaign Group will sit as MEPs- six sat in the last parliament. Other dissident voices such as Ken Coates are now gone. A mere three out of the 27 MEPs who unapologetically signed the Falconer pro 'old' Clause Four remain. Of these the senior figure is Richard Balfe, not normally identified as a leading rebel. In these circumstances it is speculating whether there will be any internal opposition from a parliamentary grouping who will be conscious that they, in part, own their selection to the leadership. 
Table 1. Gender and Ethnic Origin with 'position on list'.

\begin{tabular}{llrll}
$\begin{array}{l}\text { Position } \\
\text { on list }\end{array}$ & male & \multicolumn{1}{c}{$\begin{array}{l}\text { Sex } \\
\text { female }\end{array}$} & minority & $\begin{array}{r}\text { Ethnicity } \\
\text { white }\end{array}$ \\
$\begin{array}{l}1 \text { to } 3 \\
4 \text { and below }\end{array}$ & $\begin{array}{r}20(59 \%) \\
14(41 \%)\end{array}$ & $\begin{array}{r}12(80 \%) \\
3(20 \%)\end{array}$ & $\begin{array}{l}2(67 \%) \\
1(33 \%)\end{array}$ & $\begin{array}{l}30(65 \%) \\
16(35 \%)\end{array}$ \\
Total & $34(69 \%)$ & $15(31 \%)$ & $3(6 \%)$ & $46(94 \%)$ \\
not standing & 18 & 2 & 0 & 20
\end{tabular}

Table 2. Age of Candidate with 'position on list'.

Position on

AGE

list

\begin{tabular}{lllrrr} 
& $21-29$ & $30-39$ & \multicolumn{1}{c}{$40-49$} & \multicolumn{1}{c}{$50-59$} & $60-69$ \\
1 to 3 & $1(100 \%)$ & $8(89 \%)$ & $13(68 \%)$ & $6(50 \%)$ & $4(50 \%)$ \\
4 and below & 0 & $1(11 \%)$ & $6(32 \%)$ & $6(50 \%)$ & $4(50 \%)$ \\
Total & $1(2 \%)$ & $9(18 \%)$ & $19(39 \%)$ & $12(25 \%)$ & $8(16 \%)$ \\
not standing & 0 & 0 & 4 & 6 & $7 \& 3$ at $70+$
\end{tabular}

Table 3. Cohort with 'position on list'.

\begin{tabular}{lllllll}
\begin{tabular}{l} 
Position \\
on \\
\multicolumn{1}{c}{ list }
\end{tabular} & \multicolumn{5}{c}{$\begin{array}{l}\text { First } \\
\text { became } \\
\text { MEP }\end{array}$} \\
& 1979 & 1984 & 1989 & 1994 & 1999 & $\begin{array}{l}\text { by } \\
\text { election } \\
\text { pre-1999 }\end{array}$ \\
& & & & & \\
1 to 3 & 0 & $2(40 \%)$ & $10(83 \%)$ & $13(59 \%)$ & $5(100 \%)$ & $2(100 \%)$ \\
4 and & $3(100 \%)$ & $3(60 \%)$ & $2(17 \%)$ & $9(41 \%)$ & 0 & 0 \\
$\begin{array}{l}\text { below } \\
\text { Total }\end{array}$ & $3(6 \%)$ & $5(10 \%)$ & $12(25 \%)$ & $22(45 \%)$ & $5(10 \%)$ & $2(4 \%)$ \\
not & 3 & 10 & 6 & 1 & 0 & 0
\end{tabular}


standing

Table 4. 'Ideology' with 'Position on list'.

Position on

list

$\begin{array}{lrrlll} & \text { OLD } & \text { NEW } & \begin{array}{l}\text { Both Old } \\ \text { and } \\ \text { New }\end{array} & \begin{array}{l}\text { Neither Old } \\ \text { or New }\end{array} & \begin{array}{l}\text { Not MEP at } \\ \text { time }\end{array} \\ & & & & & \\ 1 \text { to 3 } & 4(36 \%) & 16(67 \%) & 4(67 \%) & 1(100 \%) & 7(100 \%) \\ 4 \text { and below } & 7(64 \%) & 8(33 \%) & 2(33 \%) & 0 & 0 \\ \text { Total } & 11(23 \%) & 24(49 \%) & 6(12 \%) & 1(2 \%) & 7(14 \%) \\ \text { not standing } & 14 & 5 & 1 & 0 & 0\end{array}$

Ideology

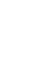

Table 5 Logistic Regression of 'Position on List' with Gender, Race, Age, Cohort and 'Newlab'.

\begin{tabular}{lrrrrr} 
Variable & \multicolumn{1}{c}{ B } & \multicolumn{1}{c}{ S.E. } & Wald & df & Sig \\
GENDER & .8549 & .8462 & 1.0206 & 1 & .3124 \\
RACE & -2.6818 & 2.2449 & 1.4271 & 1 & .2322 \\
AGE & .3761 & .4208 & .7989 & 1 & .3714 \\
COHORT & -.4818 & .4497 & 1.1475 & 1 & .2841 \\
NEWLAB & -1.0700 & .5008 & 4.5656 & 1 & .0326 \\
Constant & 3.8375 & 4.0713 & .8885 & 1 & .3459
\end{tabular}

-2 Log Likelihood

Goodness of fit 
${ }^{\mathrm{i}}$ Nearly a quarter of the EPLP elected in 1994 did not go forward to the final shortlisting committee. Of these Ken Stewart had died during the parliamentary term. Towards the end of the parliamentary term Norman West had had to resign on health grounds. Two others, Ken Coates and Hugh Kerr, were expelled by the party's General Secretary following a series of arguments about procedure and policy. In a 1995 interview with the New Times paper Coates had been quoted as saying the 'unspeakable' Blair and his self styled modernising colleagues were 'bastards' who would 'walk past' the unemployed (The Guardian 14th January 1995). Similarly Kerr had incurred the wrath of the leadership for his outspoken opposition to some of their initiatives. Both expressed their bemusement following the party's announcement of their expulsion. Disillusionment turned to anger and the pair publicly condemned the direction their former party was taking: 'New Labour is New Autocracy and is the first step in the onward march of Blair's clones' (The Guardian 8th October 1998).

Along with seven other MEPs who retired at the election, Coates, Kerr, Stewart and West had all supported the Falconer 'old' Clause Four statement. By contrast the other four stepping down had backed the alternative David text. Significantly these MEPs' decision to leave the Assembly did not necessarily mark the end of their professional political careers. The two Birmingham MEPs Christine Crawley and John Tomlinson went on to take seats in the House of Lords on the government benches. Former group leader Wayne David announced his decision to retire from the Assembly having been selected for an ostensibly safe Welsh Assembly constituency. Unfortunately for him he lost the seat to Plaid Cymru in one of the most dramatic results of that particular election.

ii It should also be noted that four MEPs who had originally been placed on a list withdrew between the announcement of the rankings and polling day. David Morris (Wales) and Alex Smith (Scotland), both signatories to the Falconer statement, did so in protest at their poor rankings. The other two cases were less straightforward. Previously a Cheshire MEP, the decision to transfer Blair supporter Lyndon Harrison to a winnable position on the Welsh list above popular sitting Member Joe Wilson caused controversy. Following an outcry within a party already convulsed by a bruising contest for the Welsh leadership, Harrison resigned and was later named as a new peer in June 1999 (The Guardian 19th June 1999). Media speculation suggested the two events were not unconnected in that Harrison's departure came at a useful point for moderniser backed candidate Alun Michael in his battle to secure the Welsh leadership. Another casuality of the system was Christine Oddy, a Falconer supporter who then recanted and backed the David text. A West Midlands MEP, she unsuccessfully appealed to the party and then threatened legal action following her relegation to an unwinnable list position. In protest at the decision, Oddy resigned the whip and announced her intention to stand as an independent and went onto to receive a reasonable vote in the election. Talking of her decision to leave the party, Oddy commented:

'I want to give voters a choice of candidate, open up the totally undemocratic nature of the closedlist system and offer the possibility of voting for a local candidate rather than two London luvvies, to mark a protest against a system which shifts power from the voters to political party elites.' (Tribune ??th ??). 
The list system was also criticised by a number of those, notably Lynne Armstrong and Joyce Edmond-Smith (both unsuccessful candidates in 1994), who had originally been selected (in their case for the South East region) but had resigned and then publicly protested about the workings of the rankings system. Writing in The Guardian (8 ${ }^{\text {th }}$ October 1998) about her preference for the OMOV process, Edmond-Smith argued that the effective exclusion of the membership from the candidate selection procedure would in effect de-energise grassroots campaigners. Commentator Polly Toynbee was similarly critical of the process. When the original lists were published, then journalist expressed dismay that the industrious East London MEP Carole Tongue had been relegated to a position on the capital's list which made her re-election far from certain (in the event Tongue did lose out). Toynbee suggested the MEP had been sacrificed by Millbank because of her advocacy of positions on media ownership which brought her into potential conflict with New Labour convert Rupert Murdoch, owner of the powerful News Corporation multi-national (The Guardian, $7^{\text {th }}$ October 1998).

Unlike Lyndon Harrison other Labour MEPs did successfully move regions: Glyn Ford moved from the North West to take the top slot in South West; Arlene McCarthy switched from the East Midlands to take the number 1 place in the North West; Anita Pollack switched from London to the a good ranking (3) in South East but lost out to the party's poor overall showing. All had endorsed the David text in support of Blair on the Clause Four debate. The only other MEP switching was by-election entrant Richard Corbett (North West to Yorkshire).

iii Of the 29 MEPs returned in 199922 had been elected in 1994. Another two (Richard Corbett and Linda McAvan) had entered the Assembly through by-elections held during the parliamentary term. Of the 5 brand new candidates, two are known supporters of Tony Blair: Michael Cashman (West Midlands), the former EastEnders actor, was elected to the Labour NEC in 1998 as part of the pro-leadership Members' First slate; Catherine Taylor (Scotland) is a former NEC Youth Representative and was an advocate of the 'new' Clause Four position. Originally fourth on the list 25 year old Taylor made a crucial move up the Scottish list (Labour won 3 seats) when the candidate ranked third, GMB union official Kathleen Walker Shaw, resigned. Walker Shaw, as the highest placed non-MEP on the list, had been obliged to fight a late 1998 by-election in the Scotland North East Euro constituency following the death of incumbent SNP member Allan MacCartney. Unfortunately for her, political opponents used the campaign to attack then government. Walker Shaw's perceived Englishness and Brussels based job were highlighted in a bid to show how remote New Labour was from the Scottish people. Unfortunately for the candidate a row over her nationality developed when it emerged she had been born in England not Scotland as was previously suggested. In a bizarre twist Walker Shaw was alleged to have explained the mix-up thus: 'It is all a misunderstanding, I was born in Stafford, but I was conceived in Aberdeen' (quoted by Lord MacKay of Ardbrecknish, House of Lords debates, $15^{\text {th }}$ December; column 1314). The party's subsequent humiliation in the by-election, coming in third behind the Conservatives in a seat Labour held up to 1994, was used by some to question what they claimed to be the authoritarian, undemocratic and ultimately self-defeating selection system (see, for instance, comments by former Scotland North East MEP Henry McCubbin, Tribune, $8^{\text {th }}$ January 1999). 